\section{Assessment of cognitive and psychomotor function and rehabilitation of elderly people with prostheses}

\section{R S Hanspal, Keren Fisher}

\section{North East Thames \\ Regional Disablement Services Centre, Harold Wood Hospital, Romford, Essex \\ R S Hanspal, FRCS, senior medical officer}

Rehabilitation Unit, Royal National Orthopaedic Hospital, Stanmore, Middlesex

Keren Fisher, CPSYCHOL, clinical psychologist

Correspondence to: Mr R S Hanspal, Disablement Services Centre, Royal National Orthopaedic Hospital Stanmore, Middlesex.

BM 1991;302:940
Over four fifths of amputations are done because of vascular or metabolic disease in elderly people, who may have other medical conditions limiting their mobility. ${ }^{1}$ Even in the absence of such medical conditions, however, elderly people with artificial limbs may not achieve the degree of mobility initially expected. Rehabilitation after amputation requires active participation by the patient and hence a minimum intellectual ability. We studied the relation between the success of rehabilitation and the intellectual state of elderly patients after amputation.

\section{Patients, methods, and results}

We studied 100 English speaking patients aged over 60 who had had one of their legs amputated ( 49 below the knee and 51 above the knee); they had subsequently achieved maximum mobility and were attending the clinic only for maintenance of the prosthesis. Thirty one were men and 69 women (mean age 72.4 years (range 61-89)). A complete clinical examination was done to grade the mobility achieved.

Cognitive and psychomotor functions were assessed with the Clifton assessment procedures for the elderly. Six scores were derived from this test: one each from the sections on orientation and mental ability; scores for the time taken and errors and a composite score for the psychomotor task (spiral maze); and a total score. All 100 patients were tested by RSH.

Pearson correlation coefficients were calculated for the six scores obtained with the cognitive assessment scale and the grades of mobility. As the grades formed a perfect Guttman scale ${ }^{3}$ and were normally distributed a parametric analysis was appropriate. Analysis by $t$ test showed that the level of amputation had no significant effect on the variables under consideration, mean total scores being 30.8 and 29.7 for patients who had had amputations below and above the knee, respectively. The effect of age, which was significantly different between the groups, was accounted for by using an analysis of covariance. ${ }^{+}$
The table shows the mean scores, results of analysis of covariance, and correlation coefficients between intellectual ability and mobility grade. The time taken to complete the maze was related to age, but all the other results were significantly different $(p<0 \cdot 01)$, indicating an association between intellectual ability and the grade of mobility that can be achieved. Differences between the grades were related to intellectual state, and the inclusion of the psychomotor task explained more of the variance than the cognitive tests alone.

\section{Comment}

The study found a highly significant correlation between scores obtained on the cognitive assessment scale and the mobility of elderly patients with a prosthesis: the higher the score the better the mobility. Even though the mobility of patients with a prosthesis is generally considered to be a purely locomotor function, the cognitive state of the patient contributed.

We used the Clifton assessment procedures for the elderly instead of other, similar tests as they can be used by nurses and therapists without special training. We included the psychomotor test as we expected thereby to gain fuller information than from the test of cognitive abilities alone.

A total score on the cognitive assessment scale of at least 30 was associated with the ability to walk indoors and outdoors in patients without medical factors limiting mobility. Only $4 \%$ of all the subjects achieved this score and were unable to walk outdoors. Only $2 \%$ of all the subjects could walk outdoors and scored less than 30 .

We are not suggesting that a patient's score on the cognitive assessment scale should be used as a strict criterion to decide whether a prosthesis should be prescribed. For some patients, achieving grade III mobility is valuable. Predicting the mobility that can be achieved, however, allows a rehabilitation package to be planned; this may include adaptations to the home, provision of a wheelchair, and training.

\footnotetext{
1 Vitali M, Robinson K, Andrews B, Harris E, Redhead R. Amputations and prostheses. 2nd ed. London: Baillière Tindall, 1986.

2 Pattie AH, Gilleard CJ. Manual of the Clifton assessment procedures for the elderly CAPE) London: Hodder and Stoughton, 1979.

3 Gutrman L. Measurements and prediction. London: Oxford University Press, 1952

4 Nie NH, Hull CH, Jenkins JG, Steinbrenner K, Bent DH. Statistial package for the social sciences. New York: McGraw Hill, 1976.
}

(Accepted 27 February 1991

Mean scores (95\% confidence intervals) achieved in tests of cognitive and psychomotor function related to grade of mobility in 100 patients with prostheses, and results of analysis of covariance and correlation coefficients

\begin{tabular}{|c|c|c|c|c|c|c|c|c|}
\hline & \multirow[b]{2}{*}{ Grade of mobility } & \multirow[b]{2}{*}{$\begin{array}{l}\text { No of } \\
\text { patients }\end{array}$} & \multirow[b]{2}{*}{$\begin{array}{l}\text { Information } \\
\text { score }\end{array}$} & \multirow[b]{2}{*}{$\begin{array}{c}\text { Mental } \\
\text { ability score }\end{array}$} & \multicolumn{3}{|c|}{ Psychomotor function $†$} & \multirow[b]{2}{*}{$\begin{array}{l}\text { Total } \\
\text { score }\end{array}$} \\
\hline & & & & & $\begin{array}{l}\text { Composite } \\
\text { score }\end{array}$ & $\begin{array}{l}\text { Time taken } \\
(\mathrm{s})\end{array}$ & $\begin{array}{l}\text { Error } \\
\text { score }\end{array}$ & \\
\hline I & Has abandoned wearing limb or uses only a cosmetic limb & 3 & $\begin{array}{c}6 \cdot 3 \\
(2 \cdot 3 \text { to } 10 \cdot 3)\end{array}$ & $\begin{array}{c}7 \cdot 3 \\
(5 \cdot 6 \text { to } 9 \cdot 0)\end{array}$ & $\begin{array}{c}4 \cdot 0 \\
(0 \text { to } 10 \cdot 0)\end{array}$ & $76 \cdot 0 \ddagger$ & $22 \cdot 0 \ddagger$ & $\begin{array}{c}17 \cdot 6 \\
(8 \cdot 8 \text { to } 26 \cdot 4)\end{array}$ \\
\hline II & $\begin{array}{l}\text { Wears prosthesis only for transfers or to help with nursing. Walks only with } \\
\text { therapist or carer }\end{array}$ & 5 & $\begin{array}{l}7 \cdot 8 \\
(5 \cdot 2 \text { to } 10 \cdot 4)\end{array}$ & $\begin{array}{c}6 \cdot 8 \\
(5 \cdot 8 \text { to } 7 \cdot 8)\end{array}$ & $\begin{array}{c}8 \cdot 6 \\
(7 \cdot 4 \text { to } 9 \cdot 8)\end{array}$ & $\begin{array}{c}81 \cdot 0 \\
(54 \cdot 8 \text { to } 107 \cdot 2)\end{array}$ & $\begin{array}{c}37 \cdot 0 \\
(22 \cdot 3 \text { to } 51 \cdot 7)\end{array}$ & $\begin{array}{c}23 \cdot 2 \\
(20 \cdot 1 \text { to } 26 \cdot 3)\end{array}$ \\
\hline III & $\begin{array}{l}\text { Walks indoors only, using walking aids (for example, sticks, crutches, or } \\
\text { Zimmer frame). Negligible walking outdoors (only with help and support } \\
\text { of others) }\end{array}$ & 24 & $\begin{array}{c}9 \cdot 7 \\
(9 \cdot 1 \text { to } 10 \cdot 3)\end{array}$ & $\begin{array}{c}8 \cdot 3 \\
(7 \cdot 7 \text { to } 8 \cdot 9)\end{array}$ & $\begin{array}{c}9 \cdot 7 \\
(9 \cdot 3 \text { to } 10 \cdot 1)\end{array}$ & $\begin{array}{c}100 \cdot 1 \\
(77 \cdot 3 \text { to } 122 \cdot 9)\end{array}$ & $\begin{array}{c}19 \cdot 8 \\
(14 \cdot 6 \text { to } 25 \cdot 1)\end{array}$ & $\begin{array}{c}27 \cdot 7 \\
(26 \cdot 8 \text { to } 28 \cdot 6)\end{array}$ \\
\hline IV & Walks indoors and outdoors, though regularly uses walking aids & 33 & $\begin{array}{c}11 \cdot 5 \\
(11 \cdot 3 \text { to } 11 \cdot 8)\end{array}$ & $\begin{array}{c}9 \cdot 0 \\
(8 \cdot 6 \text { to } 9 \cdot 4)\end{array}$ & $\begin{array}{c}10 \cdot 8 \\
(10 \cdot 6 \text { to } 11 \cdot 1)\end{array}$ & $\begin{array}{c}75 \cdot 3 \\
(66.9 \text { to } 83.7)\end{array}$ & $\begin{array}{c}9 \cdot 9 \\
(6 \cdot 6 \text { to } 13 \cdot 2)\end{array}$ & $\begin{array}{c}31 \cdot 3 \\
(30 \cdot 8 \text { to } 31 \cdot 8)\end{array}$ \\
\hline V & $\begin{array}{l}\text { Walks independently indoors and outdoors with no walking aids except } \\
\text { occasionally for confidence or to cover difficult terrain or weather conditions }\end{array}$ & 27 & $\begin{array}{c}11 \cdot 7 \\
(11 \cdot 5 \text { to } 11 \cdot 9)\end{array}$ & $\begin{array}{c}10 \cdot 2 \\
(9 \cdot 8 \text { to } 10 \cdot 6)\end{array}$ & $\begin{array}{c}11 \cdot 0 \\
(10 \cdot 8 \text { to } 11 \cdot 2)\end{array}$ & $\begin{array}{c}67 \cdot 2 \\
(58 \cdot 8 \text { to } 75 \cdot 6)\end{array}$ & $\begin{array}{c}8 \cdot 9 \\
(5 \cdot 4 \text { to } 12 \cdot 4)\end{array}$ & $\begin{array}{c}32 \cdot 9 \\
(32 \cdot 4 \text { to } 33 \cdot 4\end{array}$ \\
\hline \multirow[t]{4}{*}{ VI } & Normal or near normal gait & 8 & $\begin{array}{c}12 \cdot 0 \\
(12 \cdot 0 \text { to } 12 \cdot 0)\end{array}$ & $\begin{array}{c}10 \cdot 6 \\
(9 \cdot 9 \text { to } 11 \cdot 3)\end{array}$ & $\begin{array}{c}11 \cdot 8 \\
(11 \cdot 5 \text { to } 12 \cdot 1)\end{array}$ & $\begin{array}{c}60 \cdot 5 \\
(49 \cdot 4 \text { to } 71 \cdot 7)\end{array}$ & $\begin{array}{c}4 \cdot 3 \\
(2 \cdot 1 \text { to } 6 \cdot 5)\end{array}$ & $\begin{array}{c}34 \cdot 3 \\
(33 \cdot 5 \text { to } 35 \cdot 1)\end{array}$ \\
\hline & & df & 5 & 5 & 5 & 5 & 5 & 5 \\
\hline & & $\mathrm{F}$ & $18 \cdot 6^{\star \star \star}$ & $8 \cdot 3^{\star \star}$ & $10 \cdot 4^{\star \star \star}$ & $2 \cdot 3$ & $7 \cdot 8^{\star \star}$ & $29 \cdot 5 \star \star \star$ \\
\hline & & $r$ & $0.67^{\star \star}$ & $0 \cdot 62^{\star \star}$ & $0.62^{\star \star}$ & $-0 \cdot 29^{\star}$ & $-0.51^{\star \star}$ & $0 \cdot 82^{\star \star}$ \\
\hline
\end{tabular}

